\title{
Implementasi Kurikulum 2013 Mata Pelajaran Biologi Terintegrasi Keislaman Di Madrasah Aliyah (MA): Model Evaluasi CIPPO
}

\section{Yatin Mulyono, Sardimi, Ayatusa'adah, dan Nanik Lestariningsih}

\author{
IAIN Palangka Raya
}

\author{
Jl. G. Obos IX, Kota Palangka Raya
}

\begin{abstract}
ABSTRAK
This study is aimed at evaluating the implementation of the 2013 Curriculum 2013 at ISHS. This research is evaluative by applying the CIPPO model. The data were collected by using some observations, questionnaires and interviews. The sampling was taken by using a cluster sampling method in Central Kalimantan. The evaluation result of the 2013 Curriculum implementation for Biology course with the CIIPO analysis showed that (1) the institutional supporting level was $87.25 \%$, (2) the relevance of curriculum objectives was $76.50 \%$ (3), the teacher readiness was $38.18 \%$, (4) the facility readiness was $53.34 \%$ (5) the material readiness was $64.34 \%$, (6) the learning assessment was $90.91 \%$, and (7) the achievement of curriculum goals was $64.34 \%$. The 2013 Curriculum has not been well implemented, especially for Biology courses at ISHS.

This is due to the fact that the teachers have not been able to integrate biology science with Islam and the supporting facilities were not available for the the integration. The 2013 Curriculum implementation of Biology course at ISHS of Central Kalimantan. They caused the less-achievement of curriculum objectives.
\end{abstract}

Key words: implementation of the 2013 Curriculum; Islam-integrated; curriculum evaluation, CIPPO

\section{Pendahuluan}

Surat Edaran Menteri Agama Republik Indonesia No. SE/DJ.I/HM.01/114/204 bahwa mulai Tahun Pelajaran 2014/2015 di madrsah sudah menerapkan Kurikulum 2013. Sesuai dengan Peraturan Menteri Pendidikan dan Kebudayaan Republik Indonesia Nomor 24 Tahun 2016 Tentang Kompetensi Inti dan Kompetensi Dasar Pelajaran Pada Kurikulum 2013 Pada Pendidikan Dasar dan Pendidikan Menengah bahwa esensi Kurikulum 2013 adalah (1) mengintergrasikan Penguatan Pendidikan Karakter (PPK) didalam pembelajaran. Karakter yang diperkuat terutama 5 karakter, yaitu: religius, nasionalis, mandiri, gotong royong, dan integritas, (2) mengintegrasikan literasi; keterampilan abad 21 atau diistilahkan dengan 4C (Creative, Critical thinking, Communicative, dan Collaborative); (3) mengintegrasikan HOTS (Higher Order Thinking Skill).

Arifin (2011) menyatakan bahwa sebuah kurikulum disusun dalam rangka mencapai tujuan pendidikan, yaitu mengembangkan peserta didik yang beriman, 
bertaqwa, dan taat terhadap Tuhan Yang Maha Esa, berilmu dan berakhlak, sehat, cerdas, mandiri, bertanggung jawab serta menjadi warga negara yang baik. Pengembangan Kurikulum 2006 (KTSP) ke Kurikulum 2013 (K-13) adalah dalam rangka membekali kemampuan peserta didik sesuai dengan tuntutan zaman (Mulyasa, 2013). Implementasi K-13, peserta didik dituntut pemahaman konsep pengetahuan dan diharuskan penanaman nilai-nilai keagamaan serta penumbuhan karakter. Hal ini menyebabkan peran guru sebagai fasilitator dalam proses pembelajaran harus memahami integrasi antara materi yg disampaikan dengan nilainilai agama. Melalui integrasi tersebut akan terimplementasi dalam kehidupan sehari-hari sehingga mampu menumbuhkan sikap sosial peserta didik yang diharapkan. Terlaksananya implementasi K-13 dengan baik maka akan terbentuklah peserta didik sebagai insan kamil yang berpengetahuan, religius, dan memiliki sikap sosial yang baik.

Anas (2013) menyatakan bahwa kajian konsep integrasi pengetahuandari perspektif Islam dan tantangan yang perlu diatasi untuk membuatnya menjadi kenyataan bagi masyarakat di Malaysia. Penerapan pengetahuan "Barat" mengarah ke penyebaran pengaruh sekuler di sistem pendidikan suatu bangsa, yang pada gilirannya menyebabkan hilangnya secara bertahap identitas Islam dari masyarakat. Oleh karena itu, pendekatan integrasi pengetahuan Islam dan "Barat" perlu dikaji sebagai alternatif bagi masyarakat dalam memimpin kehidupan sehari-hari mereka didasarkan pada ajaran Islam yang benar.

Madrasah aliyah merupakan lembaga pendidikan formal sederajat dengan SLTA dibawah binaan Kementerian Agama Republik Indonesia (Kemenag RI) khususnya Direktorat Jendral Pendidikan Islam (Dirjen Pendis). Berbeda dengan sekolah dibawah binaan Kementerian Pendidikan dan Kebudayaan (Kemendikbud), distingsi madrasah lebih menguatkan nilai-nilai keislaman dalam kurikulumnya. Pada jenjang pendidikan madrasah, kompetensi yang diharapkan dari peserta didik lulusannya adalah: Mampu membaca Al-Qur'an dan memahaminya, berakhlak mulia, memahami fiqih Islam, terbiasa melakukan ibadah sehari-hari, mampu menyampaikan ceramah sederhana, dan mampu mengambil i'tibar atau pelajaran dari sejarah Islam. Selain itu, peserta didik juga diharapkan mampu: Meningkatkan keimanan dan ketakwaan yang telah ditanamkan dalam keluarga, (2) Menyalurkan bakat dan minatnya serta mengembangkannya secara optimal, (3) Memperbaiki kekurangan dan kelemahannya dalam mengamalkan ajaran Islam, (4) Menangkal pengaruh negatif kepercayaan atau budaya lain yang membahayakan keyakinan, (5) Menyesuaikan diri dengan lingkungan fisik dan sosial agar sejalan dengan ajaran Islam, (6) Menjadikan Islam sebagai pedoman hidup untuk mencapai kebahagiaan dunia dan akhirat, (7) Mampu memahami Islam secara menyeluruh sesuai dengan daya serap peserta didik dan waktu yang dimilikinya (Muhaimin, 2004).

Kurikulum 2006 (KTSP) dikembangkan menjadi Kurikulum 2013 dilandasi pemikiran tantangan masa depan yaitu tantangan abad ke 21 yang ditandai dengan JURNAL TRANSFORMATIF (Islamic Studies)

Volume 1, Nomor 2, Oktober2017 
abad ilmu pengetahuan, knowlwdge-based society dan kompetensi masa depan. Dengan demikian, kurikulum 2013 merupakan bagian terintegratif dari potonganpotongan kisah kurikulum pendidikan nasional. Karakteristik penguatan pembelajaran pada kurikulum 2013 yang mencakup: (1) menerapkan pendekatan saintifik melalui mengamati, menanya, mencoba, menalar,....(2) menggunakan ilmu pengetahuan sebagai penggerak pembelajaran untuk semua mata pelajaran, (3) menuntun peserta didik untuk mencari tahu, bukan diberi tahu (discovery learning), serta (4) menekankan kemampuan berbahasa sebagai alat komunikasi, memungkinkan anak dapat berpikir logis, sistematis, dan kreatif (Abidinsyah, 2016). Hadirnya Kurikulum 2013 pada hakikatnya sebagai penyempurna bagi kurikulum sebelumnya (KTSP), sebab idealnya kurikulum harus bersifat dinamis agar mampu menjawab tantangan dan kebutuhan zaman.

Ciri khas madrasah lebih dari hanya sekedar penyajian mata pelajaran agama. Artinya, ciri khas tersebut bukan hanya sekedar menyajikan mata pelajaran agama Islam di dalam lembaga madrasah tetapi yang lebih penting ialah perwujudan dari nilai-nilai keislaman di dalam totalitas kehidupan madrasah. Suasana lembaga madrasah yang melahirkan ciri khas tersebut mengandung unsur-unsur sebagai berikut: (1) Perwujudan nilai-nilai keislaman di dalam keseluruhan kehidupan lembaga madrasah; (2) Kedidupan moral yang beraktuaisasi, dan (3) Manajemen yang profesional, terbuka, dan berperan aktif dalam masyarakat (Tilaar \& Hapsari, 2004: 179). Dengan suasana madrasah yang demikian melahirkan budaya madrasah yang merupakan identitas lembaga pendidikan madrasah. Otonomi lembaga pendidikan madrasah hanya dapat dipertahankan apabila madrasah tetap mempertahankan basisnya sebagai pendidikan yang berbasiskan masyarakat (Community-based education) Dari sini akan lair kurikulum yang fleksibel dan sesuai dengan kebutuhan masyarakat Indonesia baru yang demokratis (Akhwan, 2014).

Karakteristik Madrasah di Indonesia adalah memiliki kurikulum, metode dan cara mengajar sendiri yang berbeda dengan sekolah pada umumnya. Madrasah memiliki karakter tersendiri, yaitu sangat menonjolkan nilai religiusitas masyarakatnya. Sementara itu sekolah merupakan lembaga pendidikan umum dengan pelajaran universal dan terpengaruh iklim pencerahan Barat. Perbedaan karakter antara madrasah dengan sekolah itu dipengaruhi oleh perbedaan tujuan antara keduanya secara historis. Tujuan dari pendirian madrasah ketika untuk pertama kalinya diadopsi di Indonesia ialah untuk mentransmisikan nilai-nilai Islam, selain untuk memenuhi kebutuhan. Kurikulum di Madrasah Aliyah memiliki ciri-ciri khas dan karakteristik tersendiri, sehingga dalam kontek kurikulum perlu menampakkan karakteritik tersebut. Pendidikan madrasah aliyah termasuk lembaga pendidikan yang sangat erat kaitannya dengan keislaman. Oleh karena itu secara umum lembaga pendidikan memiliki karakteristik menonjolkan agama dan akhlah, maksudnya segala yang diajarkan dan diamalkan didasarkan pada al-Qur'an dan Assunah. 
Kenyataan di lapangan, nilai-nilai tersebut belum terintegrasi dengan konsepkonsep mata pelajaran pengetahuan umum, termasuk Mata Pelajaran Biologi. Integrasi berasal dari bahasa Inggris "integration" yang berarti kesempurnaan atau keseluruhan. Integrasi ilmu dimaknai sebagai sebuah proses menyempurnakan atau menyatukan ilmu-ilmu yang selama ini dianggap dikotomis sehingga menghasilkan satu pola pemahaman integrative tentang konsep ilmu pengetahuan (Abidin, 2005: 49-50). Integrasi adalah menjadikan Al-Quran dan Sunnah sebagai grand theory pengetahuan, sehingga ayat-ayat qauliyah dan kauniyah dapat dipakai. Sarana dalam implementasi Kurikulum 2013 seperti buku ajar mata pelajaran pengetahuan umum, termasuk Biologi di MA belum terintegrasi dengannilai-nilai keislaman. Hal ini menyebabkan ilmu Biologi dipandang sebagai ilmu yang berdiri sendiri, hasil temuan dan kajian para ilmuan saja dan tidak bersumber dari Al-Qur'an, bahkan dianggap tidak ada sangkut-pautnya sama sekali. Penguatan ilmu keislaman di madrasah aliyah dengan memperdalam ilmu-ilmu keislaman melalui penambahan mata pelajaran keislaman, seperti mata pelajaran Al-Qur'an dan Hadis, Fiqih, Sejarah Kebudayaan Islam (SKI), Aqidah Akhlak, dan Bahasa Arab. Hal tersebut menyebabkan dikotomi antara mata pelajaran keislaman dan mata pelajaran pengetahuan umum, termasuk Biologi. Al-Qur'an merupakan sumber segala ilmu, termasuk ilmu pengetahuan, sehingga semetinya semua mata pelajaran pengetahuan umum di madrasah terintegrasi dengan ilmu keislaman.

Masruri \& Rossidy (2007) menyimpulkan bahwa konsep ilmu dalam Islam sangat komprehensif, mendalam, canggih, dan lebih komprehensif bila dibanding dengan konsep ilmu dalam pandangan Barat modern. Akhirnya, tidaklah terlalu berlebihan jika dikatakan bahwa ilmu pengetahuan kontemporer sebagaimana yang dipahami dan dikonsepsikan oleh peradaban "Barat Modern" berada pada tingkat yang rendah saat dibandingkan dan dikontraskan dengan konsep ilmu dalam Islam. Diharapkan buku ajar Biologi untuk peserta didik Madrasah Aliyah yang diintegrasikan dengan nilai keislaman dapat memberi kontribusi lebih terhadap proses pembelajaran di kelas, sehingga menjadi sarana penunjang dalam implementasi Kurikulum 2013.

\section{Metode Penelitian}

Penelitian ini bersifat evaluatif dengan menerapkan model CIPPO (context, input, process, product and outcome). Jenis penelitian ini adalah penelitian survey yang di analisis dengan pendekatan kombinasi kualitatif dan kuantitatif. Informasi kualitatif pada data kuantitatif diperlukan untuk memperkaya data dan lebih memahami fenomena sosial yang diteliti. Penelitian survey dilakukan dengan cara observasi, pengisian kuesioner dan wawancara. Survey dilakukan kepada responden untuk mengetahui implementasi Kurikulum 2013 pada pembelajaran biologi terintegrasi dengan nilai keislaman. Pendekatan kualitatif bertujuan untuk mendeskripsikan implementasi Kurikulum 2013 MA Di Kalimantan Tengah, sedangkan pendekatan kuntitatif bertujuan untuk menjelaskan hubungan antara 
tingkat kebutuhan buku ajar terintegrasi dengan keislamanmenggunakan analisis data numerik (angka) melalui metode statistik.

Populasi penelitian dalam penelitian ini adalah semua MA yang ada di Kalimantan Tengah(14 kabupaten/kota) dengan jumlah 71 MA negeri dan swata. Pengambilan sampel penelitian menggunakan metode cluster sampling(area sampling). Metode ini dilakukan dengan cara penentuan sampel kabupaten/kota, kemudian diambil sampel MA pada kabupaten/kota sampel tersebut. Wilayah populasi yang diambil 7 kabupaten/kota secara acak. Jumlah pengambilan sampel berdasarkan tabel penentuan jumlah sampel Isaac dan Michael (dalam Sugiyono, 2010) dengan tingkat kesalahan 5\%. Instrumen penelitian yang digunakan dalam penelitian ini adalah lembar observasi, instrumen kuesioner dan pedoman wawancara. Desain penelitian ini seperti Gambar 1.

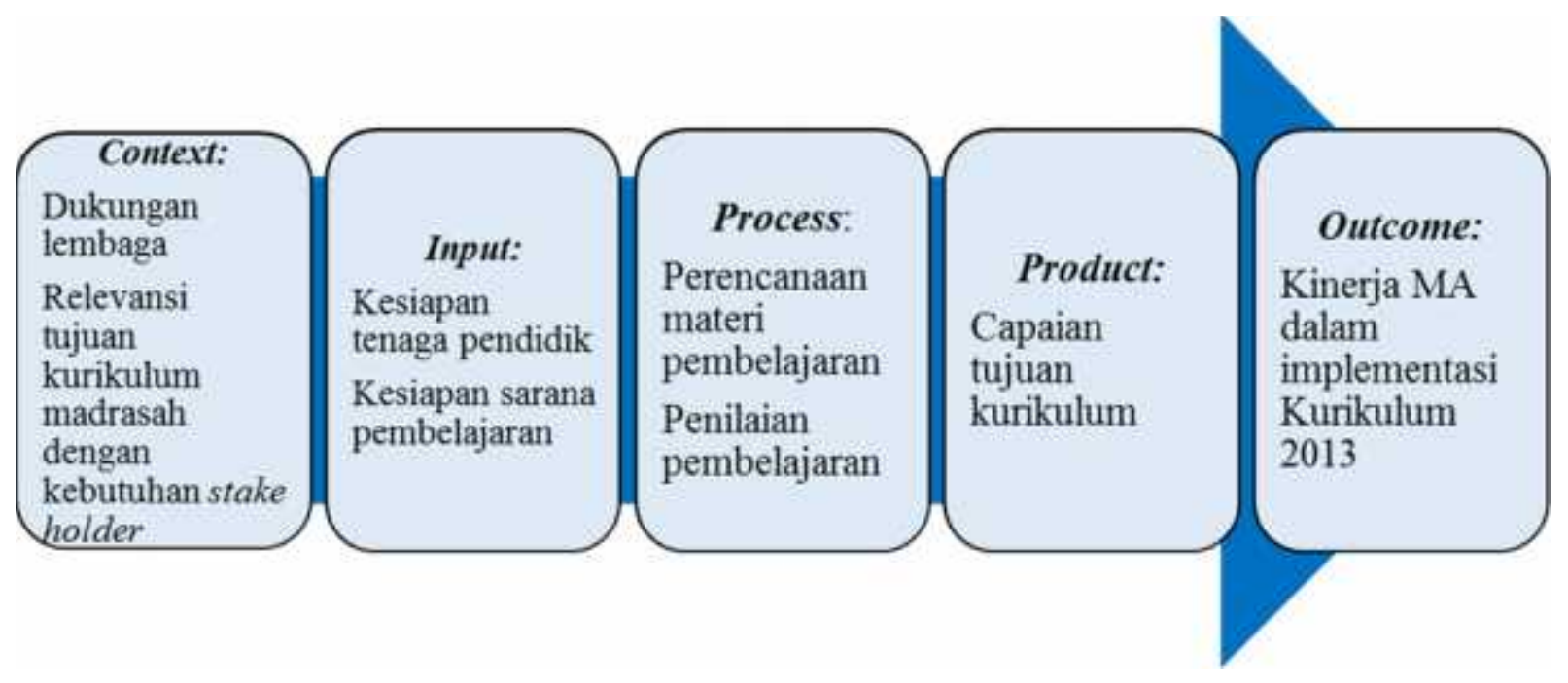

Gambar 1. Desain Penelitian Model CIPPO

\section{Hasil Penelitian Dan Pembahasan}

Hasil kuesioner evaluasi terhadap implementasi Kurikulum 2013 mata pelajaran Biologi MA di Kalimantan Tengah diperoleh hasil seperti pada pada Gambar 2.

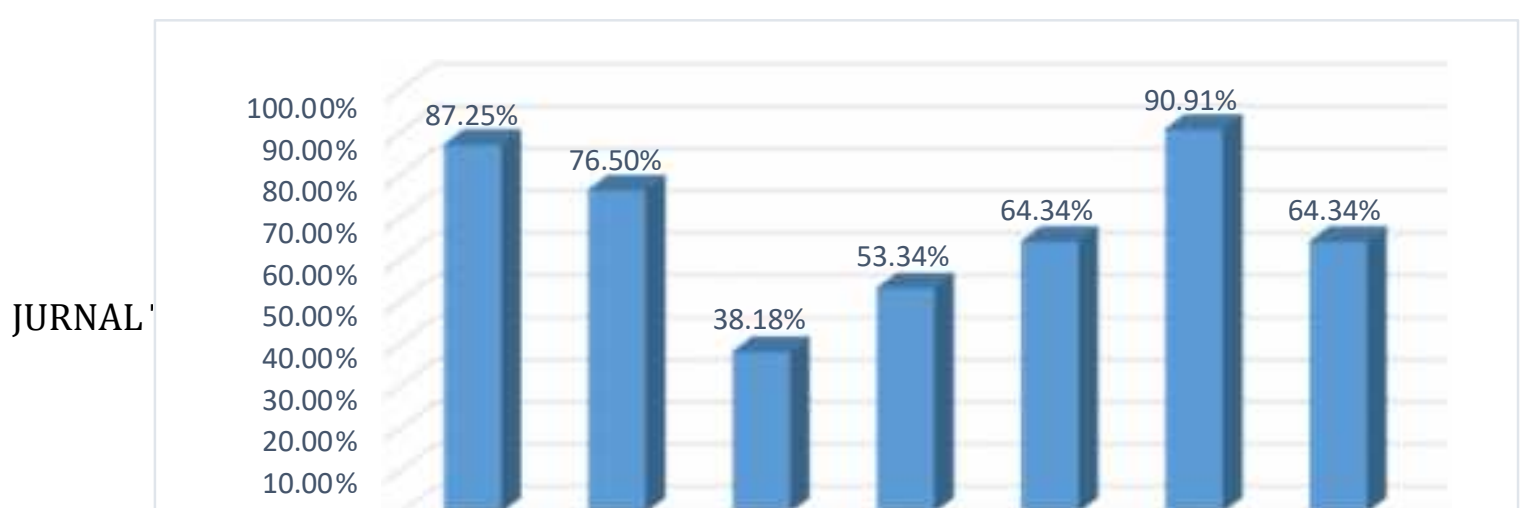


Gambar 2. Data Hasil Evaluasi CIPPO Implementasi Kurikulum 2013 Mata Pelajaran Biologi MA Di Kalimantan Tengah

Data hasil evaluasi Model CIPPO menunjukkan bahwa tingkat dukungan lembaga dalam implementasi Kurikulum 2013 dalam pembelajaran biologi di mana dari keseluruhan responden yaitu sejumlah 11 responden dalam kriteria sangat tinggi, dengan demikian maka dapat dikatakan bahwa tingkat dukungan lembaga adalah sangat tinggi atau lembaga sangat mendukung implementasi Kurikulum 2013 dalam pembelajaran biologi dengan mengintegrasikan ilmu pengetahuan (sains) dan keislaman. Tingkat pencapaian relevansi tujuan kurikulum dengan kebutuhan stake holder maka dapat dikatakan bahwa tingkat relevansi tujuan kurikulum dengan kebutuhan stake holders pada 11 MA sampel adalah tinggi. Data kesiapan tenaga pendidik dalam implementasi kurikulum 2013 bertujuan untuk mengetahui latar belakang tenaga pendidik mata pelajaran biologi. Latar belakang pendidikan tenaga pendidik mata pelajaran biologi di mana dari 11 responden, seluruhnya berpendidikan sarjana pendidikan biologi, tetapi 9 responden $(81,82 \%)$ belum mampu mengintegrasikan ilmu biologi dengan keislaman tanpa sarana/media/bahan ajar biologi yang terintegrasi dengan keislaman. Dengan demikian kesiapan tenaga pendidik mata pelajaran biologi adalah dalam katagori rendah. Data kesiapan sarana prasarana dalam implementasi Kurikulum 2013 dalam pembelajaran biologi MA di Kalimantan Tengah bertujuan untuk mendapatkan informasi fasilitas pembelajaran. Tingkat kesiapan sarana prasarana dari 11 responden menunjukkan bahwa rata-rata kesiapan sarana prasarana di MA Kalimantan Tengah dalam katagori rendah. Kesiapan materi pembelajaran dapat dilihat menunjukkan nilai rerata kesiapan perencanaan materi pembelajaran dapat dikatakan bahwa tingkat kesiapan perencanaan materi pembelajaran terkait implementasi kurikulum 2013 dalam pembelajaran biologi terintegrasi keislaman adalah sedang. Penilaian pembelajaran menunjukkan di mana dari keseluruhan responden yaitu secara umum dapat dikatakan bahwa penilaian pembelajaran dalam implementasi Kurikulum 2013 dalam pembelajaran biologi terintegrasi dengan keislaman MA di Kalimantan JURNAL TRANSFORMATIF (Islamic Studies) V Volume 1, Nomor 2, Oktober2017 
Tengah adalah tinggi. Pencapaian tujuan kurikulum dari 11 responden menunjukkan nilai rerata ketercapaian kurikulum sebesar dalam katagiri sedang.

Dukungan lembaga MA sangat penting dan akan berpengaruh terhadap hasil implementasi kurikulum. Dukungan lembaga terkait dengan hal ini antara lain dengan sosialisasi implementasi Kurikulum 2013 dan memfasilitasi workshop atau pelatihan implementasi Kurikulum 2013, khususnya oleh guru Biologi. MA memiliki kepedulian yang tinggi dalam implementasi kurikulum 2013 mata pelajaran Biologi yang merupakan program pemerintah. Relevansi tujuan kurikulum dengan kebutuhan stake holder dalam penelitian ini adalah animo masyarakat untuk sekolah di MA, sesuai dengan harapan dan manfaat yang diperoleh masyarakat bersekolah di MA.

Tenaga pendidik merupakan tenaga profesional yang bertugas merencanakan dan melaksanakan proses pembelajaran, menilai hasil pembelajaran, melakukan pembimbingan dan pelatihan. Menjadi tenaga pendidik biologi yang profesional harus memiliki kualifikasi dan kompetensi minimal sarjana pendidikan biologi. Persyaratan tenaga pendidik mengacu pada standar yang ditetapkan pemerintah atau standar yang ditetapkan oleh Madrasah Aliyah. Latar belakang pendidikan tenaga pendidik menunjukkan bahwa latar belakang pendidikan dan kompetensi yang dimiliki tenaga pendidik telah sesuai dengan program keahlian. Kesiapan tenaga pendidik ini meliputi: kesesuian kompetensi tenaga pendidik, kualifikasi tenaga pendidik, usia produktif tenaga pendidik, dan kesesuaian latar belakang pendidikan tenaga pendidik dengan program keahliannya. Dengan kategori tinggi ini membuktikan bahwa tenaga pendidik mata pelajaran biologi telah siap dalam implementasi kurikulum 2013 mata pelajaran Biologi. Tetapi dalam penginterasian terhadap keislaman, dibutuhkan pendidik biologi yang selain menguasai ilmu pedagogik dan kebiologian, juga harus menguasai ilmu keislaman. Kompetensi inilah yang masih kurang di MA Kalimantan Tengah. Hal ini disebabkan karena pendidik biologi di MA Kalimantan tengah mayoritas bukan lulusan jurusan pendidikan biologi dari perguruan tinggi berbasis agama Islam. Hasil analisis data membuktikan bahwa kesiapan sarana prasarana pembelajaran MA di Kalimantan Tengah dalam kategori rendah. Dengan kategori ini membuktikan bahwa sarana prasarana masih kurang siap dalam implementasi kurikulum 2013 mata pelajaran Biologi terintegrasi keislaman.

Perencanaan materi pembelajaran merupakan persiapan-persiapan yang dilakukan oleh tenaga pendidik sebelum melaksanakan proses belajar mengajar. Perencaan materi pembelajaran ini meliputi: peran serta tenaga pendidik dalam penyusunan silabus, keterkaitan standar kompetensi pada silabus dengan standar kompetensi lulusan, peran serta tenaga pendidik dalam penyusunan rencana pelaksanaan pembelajaran (RPP) dan peran serta tenaga pendidik dalam pembuatan modul. Perencanaan materi pembelajaran selalu mengacu pada kompetensikompetensi yang ada pada dokumen Kurikulum 2013. RPP disusun oleh tenaga pendidik melalui forum Musyawarah Guru Mata Pelajaran (MGMP) Biologi. Modul 
yang sudah ada dari berbagai sumber dikembangkan dan disesuaikan dengan kondisi madrasah. Hasil analisis menunjukkan bahwa kesiapan perencanaan materi pembelajaran dalam kategori tinggi. Hal ini menunjukkan dari segi kesiapan perencanaan materi pembelajaran di MA Kalimantan Tengah telah siap dalam implementasi kurikulum 2013 mata pelajaran Biologi.

Penilaian hasil pembelajaran mengacu pada penilaian dalam Kurikulum 2013, yaitu sikap religious, sikap sosial, pengetahuan dan keterampilan. Penilaian kemajuan belajar peserta didik secara individual dapat dilaksanakan di Madrasah Aliyah. Hal ini dikarenakan jumlah peserta didik di Madrasah Aliyah terbatas maka memungkinkan penilaian kemajuan belajar individu dilakukan, penilaian dilakukan dengan cara pengamatan secara langsung (outentik) peserta didik oleh tenaga pendidik dalam mengusai setiap kompetensi inti. Hasil analisis menunjukkan bahwa penilaian pembelajaran dalam kategori tinggi. Dengan kategori tinggi ini menunjukkan bahwa penilaian pembelajaran biologi di MA Kalimantan Tengah telah siap dalam implementasi kurikulum 2013 mata pelajaran Biologi. Hasil dari implementasi kurikulum 2013 mata pelajaran Biologi MA di Kalimantan Tengah yaitu pencapaian kompetensi inti (KI) dan kompetensi dasar (KD) yang telah ditetapkan dalam kurikulum 2013. Hasil analisis data menunjukkan bahwa evaluasi dokumen kurikulum pada MA di Kalimantan Tengah dalam kategori sedang. Hal ini menunjukkan bahwa implementasi kurikulum 2013 mata pelajaran Biologi perlu ditingkatkan. Peningkatan ini dapat dilakukan dengan program-program yang dapat menjadi solusi dari kekurangan-kekurangan implementasi Kurikulum 2013. Solusi tersebut diantaranya peningkatan kompetensi pendidik dalam ilmu keislaman dan pemenuhan sarana pembelajaran seperti buku ajar biologi yang terintegrasi dengan keislaman.

Data hasil wawancara dari 11 orang responden yang dirata-ratakan sebagai berikut: (1) hampir semuanya menjawab belum diintegrasikan dengan kesilaman, rata-rata 87,5\% menjawab belum dan sisanya menjawab sudah dintegrasi tetapi hanya sebagian materi saja yang diinterasikan. Belum ada satupun responden yang menjawab semua materi terintegrasi dengan keislaman, (2) 100\% responden menjawab setuju jika pembelajaran biologi diintegrasikan dengan keislaman (3) $62,5 \%$ responden menjawab belum tersedianya sarana pembelajaran biologi terintegrasi dengan keislaman pada MA mereka, 25\% menjawab masih kekurangan sarana pembelajaran biologi terintegrasi nilai keislaman dan sisanya 12,5\% menjawab sudah tersedia tetapi belum digunakan dengan maksimal, (4) $100 \%$ responden menjawab perlu dikembangkan buku pelajaran biologi diintegrasikan dengan keislaman, dan (4) 100\% responden menyatakan jika tersedia buku pelajaran biologi terintegrasi keislaman akan sangat membantu proses pembelajaran sekolah berbasis islam.

Hasil observasi ketersediaan buku ajar yang terintegrasi keislaman dari semua sample sekolah diketahui belum tersedia buku ajar biologi yang terintegrasi keislaman. Data hasil observasi lapangan penunjukkan bahwa buku pelajaran JURNAL TRANSFORMATIF (Islamic Studies)

Volume 1, Nomor 2, Oktober2017 
Biologi terintegrasi dengan keislaman belum tersedia dan diperlukan di MA Kalimantan Tengah. Belum tersedianya buku ini karena memang belum banyak penerbit yang menerbitkan buku pelajaran Biologi terintegrasi dengan keislaman. Padahal kurikulum 2013 lebih menekankan pada pengembangan sikap, baik sikap religi maupun sikap sosial, dan kurikulum di madrasah aliyah seyogyanya mengembangkan nilai-nilai keislaman dalam rangka mengembangkan moral peserta didik yang islami.

Reza (2013) menyatakan bahwa ada hubungan yang sangat signifikan antara religiusitas dengan moralitas remaja Madrasah Aliyah. Religiusitas pada remaja diwujudkan melalui intensitas dari serangkaian pelaksanaan ibadah. Moralitas pada remaja di wujudkan dalam pola berpikir, bersikap, dan bertindak terhadap hubungan sesama manusia yang bernilai moral. Tingkat pemahaman terhadap pelaksanaan ibadah pada remaja akan saling bersinergi dengan tingkat pemahaman norma dan nilai moral pada remaja, apabila dipahami dengan kesungguhan hati nurani. Perilaku yang bernilai moral, berasal dari hati nurani individu. Sehingga semakin tinggi tingkat religiusitas pada remaja akan diikuti tingginya pula tingkat moralitas pada remaja Madrasah Aliyah.

Menurut Masruri \& Rossidy (2007) menyatakan bahwa pembahasan tentang filsafat sains dan sains dalam pandangan Islam tidak dapat terlepas dari epistemologi atau teori ilmu dalam Islam atau al-Qur'an, sebab ilmu merupakan induk sedangkan sains merupakan cabangnya. Sains memiliki hubungan organis dengan induknya, yaitu ilmu. Dalam Islam hubungan itu terus dipertahankan, sementara Barat memisahkannya. Di samping itu, perlu ditegaskan bahwa konsep sains dan ilmu dalam pandangan Barat dan Islam di samping memiliki beberapa kesamaan, juga terdapat perbedaan yang fundamental, baik dari segi interpretasi, definisi, sumber, metode, ruang lingkup, klasifikasi, dan tujuannya.

Astuti (2010) menyatakan bahwa pengembangan kurikulum terpadu lebih menekankan pada integrasi materi pembelajaran untuk mata pelajaran seni. Model evaluasi pembelajaran harus mencakup: Konteks, yang didasarkan pada kompetensi sebelumnya dan lingkungan budaya sekolah, Desain Pembelajaran, yang didasarkan pada deskripsi konteks dan sasaran; Pelaksanaan dan Pemantauan, yang dilakukan terus menerus; Pengukuran Produk yang meliputi aspek kognitif, psikomotor, dan afektif; Pengambilan Keputusan, yang didasarkan pada produk, dan rekomendasi dalam bentuk pembelajaran. Menurut Zhang (2016) menunjukkan bahwa adanya pengaruh kualitas kurikulum dan kualitas pelayanan pendidikan terutama pada perubahan kualitas kompetensi peserta didik (outcome). Perubahan kualitas yang dirasakan ini selanjutnya berdampak langsung pada loyalitas dan secara tidak langsung mempengaruhi loyalitas melalui kepuasan. Senada dengan hal tersebut, Vanderlinde (2009) menyatakan bahwa kebijakan pemerintah dalam menetapkan kurikulum nasional akan menyebabkan perubahan implementasi pelaksanaannya di lapangan, sehingga kebijakan harus berbasis pada tujuan berdasarkan hasil evaluasi kurikulum. 
Implementasi Kurikulum 2013 di Kalimantan Tengah belum seluruhnya efektif. Hal ini karena dipengaruhi oleh faktor-foktor, antara lain tingkat dukungan lembaga, relevansi tujuan kurikulum, kesiapan tenaga pendidik, kesiapan sarana, kesiapan materi, dan penilaian pembelajaran. Jika salah satu faktor tersebut belum baik, maka akan mempengaruhi ketercapaian dalam implementasi Kurikulum 2013. Dalam hal ini, implementasi Kurikulum 2013 belum terlaksana dengan baik khususnya mata pelajaran Biologi MA. Hal ini dikarenakan belum terpenuhinya kompetensi guru mata pelajaran umum, khususnya Biologi yang mampu mengintegrasikan ilmu kebiologian dengan keislaman, serta belum tersedianya sarana penunjang untuk pengintegrasian tersebut. Hal ini sesuai dengan hasil penelitian Kanianta (2011) yang menyatakan bahwa implementasi kurikulum di sekolah belum seluruhnya efektif. Hal ini menyebabkan capaian dari tujuan kurikulum kurang maksimal.

\section{Simpulan}

Hasil penelitian dapat disimpulkan bahwa implementasi Kurikulum 2013 mata pelajaran Biologi terintegrasi keislaman masih perlu ditingkatkan terutama pada kesiapan pendidik dan sarana pembelajaran. Sarana pembelajaran di Kalimantan Tengah belum tersedia buku ajar mata pelajaran Biologi yang terintegrasi dengan keislaman. Hal ini belum memenuhi tuntutan kurikulum yang selain menuntut pengembangan ilmu pengetahuan peserta didik, juga pengembangan nilai-nilai religius dan berakhlak mulia. Tingkat kebutuhan terhadap buku ajar mata pelajaran Biologi yang terintegrasi dengan keislaman masih tinggi untuk madrasah aliyah di Kalimantan Tengah. Belum tersedianya buku ini karena memang belum banyak penerbit yang menerbitkan buku pelajaran Biologi terintegrasi dengan keislaman. Religiusitas peserta didik perlu dikembangkan karena untuk mengembangkan moralitas remaja Madrasah Aliyah. Pembahasan tentang filsafat sains dan sains dalam pandangan Islam tidak dapat terlepas dari epistemologi atau teori ilmu dalam Islam atau al-Qur'an, sebab ilmu merupakan induk sedangkan sains merupakan cabangnya.

Arah pendidikan harus relevan dengan tujuan pendidikan di Indonesia sebagaimana tercantum Undang Undang Sisdiknas No. 20 Tahun 2003, Pendidikan Nasional berfungsi untuk mengembangkan kemampuan dan membentuk watak serta peradaban bangsa yang bermartabat dalam rangka mencerdaskan kehidupan bangsa, bertujuan untuk berkembangnya potensi peserta didik agar menjadi manusia yang beriman dan bertakwa kepada Tuhan Y.M.E, berakhlak mulia, sehat, berilmu, cakap, kreatif, mandiri, dan menjadi warga negara yang demokratis serta bertanggung jawab. Perlu dipenuhinya kebutuhan buku ajar mata pelajaran biologi yang terintegrasi dengan keislaman. Dalam hal ini perlu ditindak lanjuti dengan sebuah penelitian pengembangan berdasarkan analisis kebutuhan, yaitu pengembangan buku ajar mata pelajaran Biologi terintegrasi dengan keislaman untuk madrasah aliyah. 


\section{Daftar Pustaka}

Abidin, Z. 2005. IntegrasiIlmu dan Agama: Interpretasi dan Aksi. Bandung: Mizan.

Abidinsyah, A. 2016. Kurikulum 2013 Sebagai Perwujudan Dinamika Konstruktif yang Berkarakter. Florea: Jurnal Biologi dan Pembelajarannya, 3(2): 1-8.

Anas, N. 2013. The Integration of Knowledge in Islam: Concept and Challenges. Global Journal Of Human Social Science Linguistics \&Education. Global Journals Inc. (USA). 13 (10): 51-55.

Arifin, Z. 2011. Konsep dan Model Pengembangan Kurikulum. Bandung: PT. Remaja Rosdakarya.

Astuti, K.S., Pamadhi, H., Rini, Y.S. 2010. Pengembangan Model Evaluasi Pembelajaran Seni Budaya SMP. Jurnal Kependidikan, 40(1): 87- 98.

International Council of Associations for Science Education (ICASE). 2008. Promoting Scientific and Technological Literacy (STL) for All. Second Edition. Penang: SEAMEO RECSAM.

Kanianta, I.K. 2011. Analisis Implementasi Standar Pelaksanaan Pembelajaran Pada Mata Pelajaran Produktif Kompetensi Keahlian Teknik Konstruksi Batu dan Beton (TKB) Di Sekolah Menengah Kejuruan Negeri 3 Singaraja. Jurnal Penelitian Pascasarjana Undiksha, 2 (2): 1-15.

Masruri, M.H. \& Rossidy, I. 2014. Filsafat Sains Dalam Al-Qur'an: Melacak Kerangka Dasar Integrasi Ilmu Dan Agama. Jurnal El-Qudwah, 4: 1(1-24).

Mulyasa, E. 2013. Pengembangan dan Implementasi Kurikulum 2013. Bandung: PT. Remaja Rosdakarya.

Muzhoffar Akhwan. 2014. Pendidikan Karakter: Konsep dan Implementasinya Dalam Pembelajaran di Sekolah/Madrasah. El Tarbawi: Jurnal Pendidikan Islam, 7(1): 61-67.

Reza, I.F. 2013. Hubungan antara Religiusitas dengan Moralitas pada Remaja di Madrasah Aliyah (MA). Humanitas (Jurnal Psikologi Indonesia), 10(2): 4558.

Sugiyono. 2010. MetodePenelitian Kuantitatif, Kualitatif, dan R\&D. Bandung: Alfabeta.

Tilaar, H. A. R., \& Hapsari, S. D. 2004. Multikulturalisme: Tantangan-Tantangan Global Masa Depan dalam Transformasi Pendidikan Nasional. Gramedia Widiasarana Indonesia (Grasindo). 
E-ISSN : 2580-7056, ISSN : 2580-7064

Pascasarjana IAIN Palangka Raya

Vanderlinde, R., Braak, J.V., dan Hermans, R. 2009. Educational Technology on a Turning Point: Curriculum Implementation in Flanders and Challenges for Schools. Education Tech Research Development, 57 (2): 573-584

Zhang, J., Wang, J., Min, S., Chen, K., dan Huang, H. 2016. Influence of curriculum quality and educational service quality on student experiences: A case study in sport management programs. Journal of Hospitality, Leisure, Sport \& Tourism Education, 18(1): 81-91 